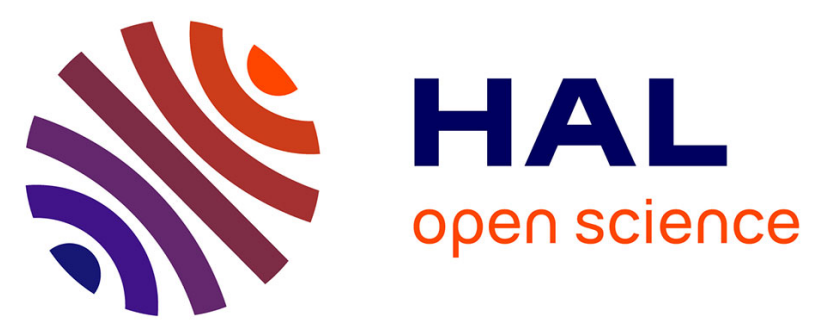

\title{
Tigecycline in the treatment of multidrug-resistant Acinetobacter baumannii meningitis Results of the Ege study
}

Oguz Reşat Sipahi, Sinan Mermer, Tuna Demirdal, Aslihan Candevir Ulu, Pierre Fillâtre, Selin Bardak Ozcem, Şafak Kaya, Alper Şener, Cemal Bulut, Recep Tekin, et al.

\section{To cite this version:}

Oguz Reşat Sipahi, Sinan Mermer, Tuna Demirdal, Aslihan Candevir Ulu, Pierre Fillâtre, et al.. Tigecycline in the treatment of multidrug-resistant Acinetobacter baumannii meningitis Results of the Ege study. Clinical Neurology and Neurosurgery, 2018, 172, pp.31-38. 10.1016/j.clineuro.2018.06.008 . hal-01833940v2

\section{HAL Id: hal-01833940}

\section{https://hal-univ-rennes1.archives-ouvertes.fr/hal-01833940v2}

Submitted on 14 Sep 2018

HAL is a multi-disciplinary open access archive for the deposit and dissemination of scientific research documents, whether they are published or not. The documents may come from teaching and research institutions in France or abroad, or from public or private research centers.
L'archive ouverte pluridisciplinaire HAL, est destinée au dépôt et à la diffusion de documents scientifiques de niveau recherche, publiés ou non, émanant des établissements d'enseignement et de recherche français ou étrangers, des laboratoires publics ou privés. 
Tigecycline in the treatment of multidrug-resistant Acinetobacter baumannii meningitis: Results of the Ege study

Oguz Reşat Sipahi ${ }^{*}$, Sinan Mermer ${ }^{1}$, Tuna Demirdal ${ }^{2}$, Aslıhan Candevir Ulu ${ }^{3}$, Pierre Fillatre ${ }^{4}$, Selin Bardak Ozcem $^{5}$, Şafak Kaya ${ }^{6}$, Alper Şener ${ }^{7}$, Cemal Bulut $^{8}$, Recep Tekin $^{9}$, Hasip Kahraman $^{10 *}$, Erkin Özgiray ${ }^{11}$, Taşkın Yurtseven $^{11}$, Hilal Sipahi ${ }^{12}$, Bilgin Arda ${ }^{1}$, Hüsnü Pullukçu ${ }^{1}$, Meltem Taşbakan ${ }^{1}$, Tansu Yamazhan ${ }^{1}$, Sohret Aydemir $^{13}$, Sercan Ulusoy ${ }^{1}$

${ }^{1}$ Ege University Faculty of Medicine; Department of Infectious Diseases and Clinical Microbiology, Izmir, Turkey.

${ }^{2}$ Izmir Katip Celebi University, Department of Infectious Diseases and Clinical Microbiology, Izmir, Turkey.

${ }^{3}$ Cukurova University; Department of Infectious Diseases and Clinical Microbiology, Adana, Turkey.

${ }^{4}$ et Maladies Infectieuses Réanimation Médicale, Hôpital Pontchaillou, Rennes, France; CIC-Inserm-0203,

Faculté de Médecine, Université Rennes 1, Rennes, France.

${ }^{5}$ Dr Burhan Nalbantoglu State Hospital, Infectious Diseases Clinic, Nicosia, Northern Cyprus.- Yakin Dogu

University Hospital, Department of Infectious Diseases and Clinical Microbiology, Nicosia, Cyprus.

${ }^{6}$ Diyarbakir Gazi Yasargil Educational and Research Hospital, Infectious Diseases Clinic, Diyarbakir, Turkey.

${ }^{7}$ Canakkale Onsekiz Mart University, Department of Infectious Diseases and Clinical Microbiology, Canakkale, Turkey.

${ }^{8}$ Ankara Training and Research Hospital, Infectious Diseases Clinic, Ankara, Turkey.

${ }^{9}$ Dicle University Faculty of Medicine, Department of Infectious Diseases and Clinical Microbiology, Diyarbakir, Turkey.

${ }^{10}$ Datca State Hospital, Mugla, Turkey

${ }^{11}$ Ege University Faculty of Medicine; Department of Neurosurgery, Izmir, Turkey

12 Bornova Public Health Directorate, Izmir, Turkey

${ }^{13}$ Ege University Faculty of Medicine; Department of Microbiology and Clinical Microbiology, Izmir, Turkey

\section{*Corresponding author:}

Hasip Kahraman

Datca State Hospital

Infectious Diseases and Clinical Microbiology Clinic

48900, Datca, Mugla, Turkey

hasipkahraman@gmail.com

Fax: 00902323904770

Tel: 00905069729666 


\title{
Highlights
}

- Multidrug resistant Acinetobacter is an important cause of nosocomial meningitis.

- Treatment options are limited and mostly based on susceptibility test results.

- Data regarding tigecycline vs Acinetobacter meningitis is limited to case reports.

- This study suggests that tigecycline may be used at least as a salvage therapy option.

- It may be used in combination with other agents for Acinetobacter meningitis.

\begin{abstract}
Objectives: In this study we retrospectively reviewed A. baumannii meningitis cases treated with tigecycline including regimens and evaluated the efficacy of tigecycline in the therapy.

Patients and Methods: Study was performed in seven tertiary-care educational hospitals from five cities of Turkey and one center from France. We extracted data and outcomes of all adult (aged>18) patients with culture proven A. baumannii meningitis treated with tigecycline including antibiotic therapy until April 2016.

Results: A total of 23 patients (15 male and eight female) fulfilled our inclusion criteria. All Acinetobacter strains were carbapenem-resistant and susceptible to tigecycline. Six cases received tigecycline monotherapy while 17 received tigecycline including combination therapy (10 with colistin, 4 with netilmicin, 3 with amikacin, 4 with meropenem). Seven of 23 cases $(30 \%)$ died during the tigecycline including therapy (1 in monotherapy, 4 in colistin, 2 in netilmicin, 1 amikacin, one case received tigecycline+netilmicin followed by tigecycline+colistin). Hence, overall end of treatment (EOT) success was $70 \%$. However, since further $27 \%$ died due to additional nosocomial infections, overall clinical success (relieved symptoms at the EOT and one-month post-therapy survival without any relapse or reinfection) decreased to $43 \%$.
\end{abstract}


Conclusion: We conclude that tigecycline may be an alternative in the salvage treatment of nosocomial multidrug-resistant Acinetobacter spp. meningitis

Key words: Acinetobacter baumannii; meningitis; glycylcycline; multidrug resistant bacteria, carbapenemresistant

\section{Introduction}

In spite of developments in neurosurgery, antimicrobial agents, medicine and intensive care, meningitis, as well as nosocomial or healthcare-associated meningitis (HCAM), are still associated with significant mortality and morbidity [1-11]. Multidrug-resistant (MDR) as well as carbapenem-resistant Acinetobacter baumannii (CRAB) is an important global problem in any kind of nosocomial infection [4,12-16]: Acinetobacter spp is also one of the most common bacterial agents in the etiology of HCAM and the most common one in Turkey [1,3]. Treatment options are limited and depend on the susceptibility pattern of the infecting isolate [1]. Tigecycline is a glycylcycline antimicrobial agent, active in vitro against a variety of Gram-positive and Gram-negative organisms including CRAB [1,4,17-19]. The United States Food and Drug Administration (FDA) approved tigecycline for the treatment of complicated intra-abdominal infections, complicated skin and skin structure infections and community-acquired pneumonia. However, its off-label use in other CRAB infections such as nosocomial pneumonia, bacteremia or meningitis is common due to its pharmacological profile and bacterial spectrum [5-10]. In this multicenter study, we retrospectively reviewed A. baumannii meningitis cases treated with tigecycline including regimens and evaluated the efficacy of tigecycline in the therapy.

The datasets generated during and/or analysed during the current study are available from the corresponding author on reasonable request. 


\section{Materials and methods}

This study was performed in seven tertiary-care educational hospitals from five cities of Turkey (Izmir, Ankara, Adana, Çanakkale, Diyarbakir) and one hospital from Rennes-France. We extracted data and outcomes of all adult (aged $>18$ ) patients with culture-proven A. baumannii meningitis treated with tigecycline including therapy between January 2007-April 2016. Demographic, clinical and laboratory findings, predisposing factors, as well as information on response to treatment and outcome were obtained retrospectively by the study site authors. Ege University Institutional Review Board approved the study.

A definite diagnosis of meningitis was based on the isolation of A. baumannii in at least one CSF culture. Typical CSF findings included a leukocytosis with a predominance of polymorphonuclear cells $(\geq 250$ leukocytes/ml), and classical clinical manifestations of meningitis. Nosocomial meningitis was defined as bacterial infection not present when the patient was admitted to the hospital or clinical evidence of infection within a short period of time after discharge from the hospital where the patient had received an invasive procedure. Patients developing meningitis after neurosurgical procedures were defined as having postneurosurgical infection $[11,20]$. Accordingly, all cases had nosocomial post neurosurgical meningitis.

CSF samples were obtained by lumbar puncture or percutaneous aspiration of shunt reservoir or puncture of extra ventricular drainage tubing. Samples were routinely centrifuged and the pellet was Gram stained. Identification of A.baumannii and determination of antimicrobial susceptibility were performed using the VITEK 2 automated system (BioMerieux Inc, Mercy L'etoil, France) and conventional methods. For tigecycline susceptibility, the FDA clinical minimum inhibitory concentration (MIC) breakpoints for Enterobacteriaceae (2 mg/l-sensitive) were used. Other antibacterial susceptibility tests were evaluated according to Clinical Laboratory Standards Institute (CLSI) criteria until 2014 and EUCAST in 2015 and 2016 [21,22].

Microbiological success was defined as clearance of A. baumannii in repeated CSF cultures on day 3-5 and/or at the end of tigecycline including treatment (EOT). EOT success was defined as relieved symptoms (which were present at the beginning) at the end of treatment accompanied by microbiological success. Overall success was defined as EOT success and one-month post-therapy survival without any relapse or reinfection.

Fisher exact test was used for comparison of major treatment groups. 


\section{Results}

A total of 23 patients (15 male and eight female) fulfilled our inclusion criteria. All cases were in intensive care units at the beginning of the tigecycline including therapy. Gender, age, underlying diseases and other characteristics of the cases, are shown in table 1 and 2.

\subsection{Clinical presentation and diagnosis}

Five cases had shunt infection (2/6 in tigecycline monotherapy group vs 3/17 in others, p:0.57), 12 were on lumbar drainage (6/6 in tigecycline monotherapy group vs 6/17 in others, p:0.013) whereas seven were on external ventricular drainage on the day of CRAB meningitis ( $0 / 6$ in tigecycline monotherapy group vs $7 / 17$ in others-p:0.12- lumbar drainage or external ventricular drainage 6/6 vs 13/17 p:0.53)

Twenty-one cases had disturbances in the level of consciousness (6/6 in tigecycline monotherapy group vs $15 / 17$ in others, p:1) and 11 had neck stiffness (6/6 in tigecycline monotherapy group vs 5/17 in others, p:0.0048). Nineteen cases had a fever (5/6 in tigecycline monotherapy group vs 14/17 in others, p:1). Six cases had convulsions (2/6 in tigecycline monotherapy group vs 4/17 in others, p:0.63) and twelve had nausea and vomiting (5/6 in tigecycline monotherapy group vs 7/17 in others, p:0.155) (Table 1).

Twenty patients had leukocytosis $\left(>10.000 / \mathrm{mm}^{3}\right)$. Three cases did not have leukocytosis but had polymorphonuclear leukocyte predominance (Table 1). Glasgow coma scale results of all cases at the start of tigecycline including therapy are in table 2 .

All cases had CSF pleocytosis (median $500 / \mathrm{mm}^{3}$, range $280-3450 / \mathrm{mm}^{3}$, Table 1). Mean CSF protein level was 299 mg/dl (range 38-2055 mg/dl, table 1), Mean CSF glucose level was 41 mg/dl (range 1-60 mg/dl, table 1). All cases had culture-proven A. baumannii meningitis. Case 12 had mixed infection with E. faecium. All A. baumannii strains were carbapenem-resistant (only two intermediately-resistant). All strains were susceptible to tigecycline. Seventeen strains were susceptible to colistin while colistin susceptibility was unknown in six strains. Nine and three strains were susceptible to netilmicin and amikacin, respectively. Tigecycline MIC was available in two cases and was $0.5 \mathrm{mg} / \mathrm{L}$ in both.

\subsection{Previous antibacterial treatment}

When we evaluated the antibiotic therapy history of the cases during the one-month time period before the $A$. baumannii meningitis episode, all but five received at least one antibiotic (2/6 in tigecycline monotherapy group vs 16/17 in others, p:0.15). The most commonly used antibiotic was vancomycin (8 cases). Seven cases received 
meropenem while five cases received cefazoline. Others are detailed in table 2. Eleven cases had received empirical (Case 10-13-14-15-16-17-18-19-20-21-22; 0/6 in tigecycline monotherapy group vs 11/17 in others, p:0.07) meningitis therapy before tigecycline including regimens.

\subsection{Tigecycline Including CRAB Meningitis treatment}

Data related to the duration of treatment regimens are summarized in table 1 . Tigecycline dosage was $50 \mathrm{mg}$ $\mathrm{q} 12 \mathrm{~h}$ in all cases. Six cases received tigecycline monotherapy (Case 1-6), while 17 received tigecycline including combination therapy (10 with colistin, 4 with netilmicin, 3 with amikacin, 4 with meropenem-Table 2), Tigecycline level in cerebrospinal fluid or sera was not measured in any case.

Ten cases received tigecycline+colistin (Case 7-16). Of these ten, three received concomitant intrathecal colistin (case 9-13 and 15). In case 16 tigecycline and netilmicin (3 days intrathecal and 6 days intravenous) combination was started. Afterwards, netilmicin was switched to colistin due to microbiological failure. In case 11 colistin was switched to meropenem after nephrotoxicity on day 5. Case 14 received additional rifampin as third antibacterial agent. Case 12 received additional vancomycin also for E. faecium meningitis.

Four cases were given tigecycline and netilmicin combination (Case 16-19). In case 16 tigecycline and netilmicin (3 days intrathecal and 6 days intravenous) combination was started. Afterwards, netilmicin was switched to colistin due to microbiological failure. In case 17 linezolid was also added to antibiotic therapy empirically. In case 18 tigecycline and netilmicin were started after failure with cefoperazone/sulbactam and meropenem. Case 19 received netilmicin for three days intrathecally and five days intravenously.

Three cases received tigecycline and amikacin including therapy (Case 20-21-22). Case 22 received amikacin only intrathecally in combination with meropenem and case 21 received additional rifampin as third antibacterial agent.

Finally, four cases (Case 11, 12, 22 and 23) were given tigecycline and meropenem including therapy. Case 11 received meropenem after colistin nephrotoxicity. Case 12 received additional colistin while case 22 received additional intrathecal amikacin. In case 11 and 22 the infecting srains were intermediately resistant to meropenem.Case 12 and 23 received meropenem despite the infecting strain was resistant to it.

\subsection{Microbiological response on day 3-5}

Repeated CSF culture on day 3-5 was available for 18 cases and overall efficacy was 72\% (13/18, table 1). Among these 18 cases, microbiological efficacy on day 3-5 was evident in 5 of 5 cases in monotherapy group, 4 
of 8 in tigecycline+colistin group, 1 of 3 in tigecycline+netilmicin group, 2 of 2 tigecycline+amikacin group and in $2 / 2$ in cases received tigecycline+meropenem combination. There was no significant difference between the monotherapy vs any combination therapy (p:0.128).

Tigecycline monotherapy (Case 1-6): Microbiological response data on day 3-5 were available for five cases all of whom had CSF clearance at both time points. Case 5 did not have repeated CSF culture and died on day 5 possibly due to meningitis.

Tigecycline and colistin including therapy (Case 7-16): Eight of 10 cases had repeated CSF culture on day 3-5 and four had bacteriological eradication (Case 9, 10, 12, 14). Two cases (Case 7 and 11) did not have repeated CSF culture. However, case 7 had clinical response at the end of therapy and had one-month survival without any relapse. Case 11 died during therapy.

Tigecycline and netilmicin including therapy (Case 16-19): Three of four cases had repeated CSF culture on day 3-5 and two (Case 17 and 18) had bacteriological eradication. Case 16 had bacteriologic failure with tigecycline and netilmicin combination and netilmicin was switched to colistin. Case 19 did not have repeated CSF culture but had clinical response at the end of therapy and had one-month survival without any relapse.

Tigecycline and amikacin including therapy (Case 20-22): Two of three cases had repeated CSF culture on day 3-5 and one (Case 22) had bacteriological eradication. Case 21 did not have repeated CSF culture on day 3-5.

Tigecycline and meropenem including therapy (Case 11, 12, 22 and 23): Case 11 did not have repeated CSF culture on day 3-5. Other cases had bacterial eradication on day 3-5.

\subsection{End of therapy microbiological response}

EOT microbiological efficacy data were available in 17 cases and overall efficacy was 88\% (15/17). Microbiological efficacy at the end of the treatment was evident in 5 of 5 in monotherapy group, 6 of 7 tigecyclin+colistin group, 1 of 3 tigecycline+netilmicin group, 2 of 3 tigecycline+amikacin group and 2/2 of cases who received tigecycline+meropenem combination.

Tigecycline monotherapy (Case 1-6): Microbiological response data at the EOT were available for five cases all of whom had CSF clearance. The only case who had not microbiological response data died on day 5 of tigecycline monotherapy.

Tigecycline and colistin including therapy (Case 7-16): Seven cases had EOT CSF culture and six had bacteriological eradication (Case 9, 10, 13, 14, 15, 16). The case with bacteriological failure (case 8) died. 
Among three cases without EOT CSF culture data one (Case 11) died during therapy whereas two had EOT as well as one-month survival without any relapse (Case 7 and 12).

Tigecycline and netilmicin including therapy (Case 16-19): Only one case (Case 18) had EOT CSF culture and had bacteriological eradication. Case 17 had bacteriological cure on day 3-5 but died during treatment. Case 19 did not have EOT CSF culture but had EOT clinical response as well as one-month survival without any relapse. In case 16 was netilmicin was switched to colistin after failure.

Tigecycline and amikacin including therapy (Case 20-22): Three cases had EOT CSF culture. Two (Case 20 and 22) had bacteriologic cure whereas one (Case 21) had developed P. aeruginosa meningitis during the tigecycline including therapy.

Tigecycline and meropenem including therapy (Case 11, 12, 22 and 23): Case 22 and 23 had EOT CSF culture data and both had bacterial cure. Case 11 died during therapy whereas case 12 had EOT as well as one-month survival without any relapse or reinfection.

\subsection{Clinical success and mortality}

Seven of 23 cases $(30 \%)$ died during the tigecycline including therapy (1 in monotherapy, 4 in colistin, 2 in netilmicin, 1 amikacin, case 16 received tigecycline+netilmicin followed by tigecycline+colistin). Hence, EOT clinical success was $70 \%$

Among the remaining 16 cases, one had relapsing A. baumannii meningitis, one case had reinfection with P.aeruginosa, one case had reinfection with MRSA and three cases died due to nosocomial pneumonia during one-month follow-up. Hence. overall clinical success (relieved symptoms at the end of treatment and one-month post-therapy survival without any relapse or reinfection). was $43 \%(10 / 23)$. There was no difference in terms of EOT clinical success (5/6 vs 11/17, p: 0.62) and clinical success at the end of one-month follow-up (2/6 vs 8/17, p:1) in monotherapy vs any combination group. Glasgow coma scale at the EOT was 15 in two cases, 14 in four and 13 in one case. Others' EOT Glasgow coma score was 12 or less (table 2). When tigecycline monotherapy was compared with tigecycine+aminoglycoside combination or tigecycline+colistin there was no significant difference $(\mathrm{p}>0.05)$.

Tigecycline monotherapy (Case 1-6): The five cases with bacterial clearance in CSF had EOT clinical success. However, three of them died due to nosocomial pneumonia during follow-up. The only case without EOT clinical success had died on day 5 of tigecycline possibly due to meningitis. 
Tigecycline and colistin including therapy (Case 7-16): Five cases had EOT clinical success and did not have relapse/reinfection during one-month follow-up (Case 7, 10, 12, 13, 14). In contrast, four cases died (two died possibly due to CRAB meningitis episode (Case 9 and 11), one nosocomial Providencia stuartii sepsis (Case 16) and one nosocomial meningitis and/or central catheter infection (Case 8). One case (Case 15) had EOT clinical response but had relapse on day 22 after treatment was retreated with tigecycline and colistin combination successfully and had no relapse during follow-up.

Tigecycline and netilmicin including therapy (Case 16-19): Two cases (Case 18 and 19) had EOT clinical response. Case 19 had no relapse/reinfection during one-month follow-up. However, case 18 had reinfection with MRSA meningitis. Case 16 who was switched to tigecycline+colistin, died possibly due to $P$. stuartii sepsis (Case 16) and case 17 died secondary to meningitis episode.

Tigecycline and amikacin including therapy (Case 20-22): Case 20 had EOT clinical success and no relapse/reinfection during one-month follow-up. Case 22 who received tigecycline, amikacin and meropenem combination during treatment died on day 26 possibly due to meningitis episode. Case 21 who received tigecycline, amikacin and rifampin combination had clearance of A. baumannii but developed P. aeruginosa meningitis on follow-up.

Tigecycline and meropenem including therapy (Case 11, 12, 22 and 23): Case 12 and 23 had EOT clinical response and no relapse/reinfection during one-month follow-up. Although case 22 had bacterial clearance in CSF culture, he died probably due to nosocomial sepsis and possibly meningitis. Case 11 died during the treatment possibly due to meningitis.

Microbiological response, as well as clinical response at the end of therapy and after one-month follow-up, are summarized in table 2 .

\subsection{Adverse events}

There was increase in creatinine levels in two cases who received tigecycline-colistin combination in one of whom colistin was switched to meropenem. Two cases had mild hepatotoxicity (x2 AST-ALT) levels which also did not result in change in antibiotic therapy. There was no severe hematological, nephrological or hepatological toxicity during the tigecycline treatment of other cases.

\section{Discussion}

Nosocomial Acinetobacter infections including meningitis are becoming an increasingly common problem in intensive care units. In a recent systematic review regarding HCAM in Turkey [3], Acinetobacter spp. caused 
$30.7 \%$ of cerebrospinal fluid culture positive 899 nosocomial meningitis episodes. Pooled carbapenem resistance rate was $37.5 \%$. CRAB is endemic in many Turkish hospitals. According to pooled national nosocomial infection surveillance data, 50 percentile of the carbapenem-resistance rate of $A$. baumannii in tertiary-care university hospitals was $93.66 \%$ in 2014 [12]. Carbapenem resistance rate in Acinetobacter is reported to be over $>50 \%$ in several countries including Italy, England, Saudi Arabia, China, India, Brazil and Argentina and United States [13].

There are several options in the treatment of CRAB meningitis cases according to susceptibility pattern of the relevant strain such as colistin, sulbactam, aminoglycosides and tigecycline $[1-3,14,15]$. In the presented study all strains were susceptible to tigecycline. Data regarding tigecycline in meningitis or $A$. baumannii meningitis is rare [6,7,16,23-28]. To our knowledge, there are a few reports in which tigecycline is used to treat $A$. baumannii meningitis. Wadi et al [6] treated a case of $A$. baumannii meningitis with tigecycline monotherapy successfully. Tutuncu et al [7] reported two cases of A. baumannii meningitis treated with tigecycline+netilmicin. Kooli et al reported successful treatment of an A. baumannii meningitis case with tigecycline and colistin combination [16]. Recently there have been cases reported to be treated with intrathecal tigecycline regimens [26-28]. Data related to animal models are also scarce about tigecycline. Wang et al compared tigecycline with tigecycline+vancomycin in Streptococcus pneumoniae meningitis of rabbits and reported that combination therapy was associated with greater clearance. However, the significance of the results obtained with the combination is limited by the absence of statistical analysis comparing the different arms $[9,10]$. Fang et al [17] analyzed the effects of tigecycline at different doses with or without vancomycin on penicillin-resistant $S$. pneumoniae induced meningitis model. In their study, when used at a concentration above $20 \mathrm{mg} / \mathrm{kg}$, tigecycline was reported to be bactericidal and was at concentration above $1 \mathrm{mg} / \mathrm{ml}$ in CSF after three $\mathrm{h}$ of treatment. In case of $A$. baumannii meningitis, to our knowledge there is no animal study comparing tigecycline with any antibacterial agent.

Herein we presented $23 \mathrm{CRAB}$ meningitis cases treated with tigecycline including regimens. Six cases received monotherapy. Several meta-analysis regarding tigecycline in randomized-controlled studies concluded excess mortality in tigecycline arm [18,19]. Colistin entered Turkish market in 2011. Most cases but not all received 
colistin including combination. Hence, some of the cases were combined with non-colistin options whereas some others were treated with monotherapy.

Data regarding penetration of tigecycline into CSF is rare. Ray et al [23] reported a serial, steady-state, serum and CSF concentrations of tigecycline when administered in the Food and Drug Administration-approved dose of $50 \mathrm{mg}$ every 12 hours. CSF concentrations remained relatively stable, suggesting that tigecycline did not accumulate in the CSF. Tigecycline concentrations in the CSF were between 0.035 and $0.048 \mathrm{mg} / \mathrm{L}$, while corresponding serum concentrations were $0.097-0.566 \mathrm{mg} / \mathrm{L}$. The calculated tigecycline penetration ratio in this patient ranged from $0 \%$ to $52 \%$, depending on the calculation methodology utilized. In another case with shunt infection regarding penetration of tigecycline [24], the deep concentration of tigecycline (before the following expected administration, t0) was $49 \mathrm{ng} / \mathrm{ml}$ in serum and $5.2 \mathrm{ng} / \mathrm{ml}$ in the CSF at steady-state. At $1 \mathrm{~h}$ after the end of the infusion, the drug serum concentration was $203 \mathrm{ng} / \mathrm{ml}$ and the CSF concentration was $13.4 \mathrm{ng} / \mathrm{ml}$. The average ratio of CSF-to-serum concentration was 0.079 (0.059-0.106 interval). Lengerke et al [25] reported higher tigecycline level in inflamed CSF vs non-inflamed CSF and suggested that higher tigecycline levels may cause higher CSF levels. Interestingly, in recently published three case reports [26-28] tigecycline was administered by intraventricular route possibly because of the severity of these infections ( 2 A. baumannii and 1 K. pneumoniae meningtis/ventriculitis) and the limited treatments available. Wu et al also analysed the pharmacokinetics of tigecycline and measured tigecycline concentrations by liquid chromatography-mass spectrometry/mass spectrometry. The trough concentrations of tigecycline in CSF for the three different dosages of tigecycline IV-intra ventricular (ICV) combined administration were $0.313,1.290$ and $2.886 \mathrm{mg} / \mathrm{L}$ for 40mgIV/10mgICV, $45 \mathrm{mgIV} / 5 \mathrm{mg} \mathrm{ICV}$ and $50 \mathrm{mg}$ IV /1 mg ICV tigecycline, respectively. In terms of outcome, in the case reported by $\mathrm{Wu}$ et al, [27] clinical success but microbiological success is not mentioned, while Lauretti et al. [26] and Fang et al [28] reported both clinical and microbiological success. In our series none of the cases received intrathecal or intravenous high dose tigecycline probably due to the fact that all strains were susceptible to tigecycline and/or reimbursement problems. Additionally since the presented study was on retrospective design, tigecycline levels could not be measured in any case.

Seven of 23 cases (30\%) died during the tigecycline including therapy. Hence, overall EOT success was $70 \%$. However, since further $27 \%$ died due to other nosocomial infections, overall clinical success (relieved symptoms 
at the EOT and one-month post-therapy survival without any relapse or reinfection) decreased to $43 \%$. Mortality was the least in monotherapy arm (17\%) whereas it was $40 \%$ in cases who received tigecycline+colistin $(p>0.05)$ and only three received intrathecal colistin (one of these three cases survived after one-month follow-up). In the systematic review by Falagas et al, [29] which comprised 11 A. baumannii meningitis cases, treated with intrathecal colistin including therapy, intrathecal colistin was found to be successful in 10 cases. The difference between the outcomes of the studies may be due to the differences in the time lap between the A. baumannii oriented therapies or relatively low number of cases receiving intrathecal colistin which is reported to be associated with a better clinical response in some series [30,31]. Another speculative reason may be the antibacterial effect of the antibiotic combination on the infecting strain. Combination therapy for CRAB infections is mostly recommended to cause synergy. However, the results of synergy tests are rarely known at the start of therapy. In fact, as in the presented study, it is usually not performed. In the real life scenario, a combination may be synergic in one strain whereas antagonistic in other [32]. In the previously mentioned systematic review regarding nosocomial meningitis in Turkey, pathogen-specific mortality was reported to be $55.5 \%$ (30/54) for A. baumannii [3]. Finally, overall one-month survival was $46 \%$ in another paper regarding tigecycline therapy in 72 Acinetobacter nosocomial pneumonia cases [5]. Hence, although EOT clinical success of $70 \%$ is comparable, one month survival without reinfection or relapse was a bit less than general $A$. baumannii meningitis outcomes $(55.5 \%)$ and comparable to MDR A. baumannii pneumonia results in our setting.

Our study has several limitations. It was not a formal therapeutic trial but rather a retrospective review of cases treated with tigecycline including regimens. Besides, we did not make a sample size analysis for detecting the power of therapeutic efficacy comparison. We did not perform multiple logistic regression analysis for mortality since total number of cases was low and we did not have 10-20 events per covariate [33]. The relatively low number of cases probably resulted in not to achieve statistical significance in other comparisons, too. There was no pharmacokinetic and pharmacodynamic data, as CSF/blood levels of tigecycline were not measured in any case. Besides, molecular genetic analysis of the infecting strains could not be performed since strains were not available. In addition, since autopsy could not be performed, definite reasons for mortality could not be delineated. Only six cases were treated with monotherapy. Some of the cases received additional intrathecal therapy. Hence, success or failure in 17 cases was not due to tigecycline alone but also the effects of combination and/or intrathecal therapy. However, as mentioned before, tigecycline was reported to be associated with excess 
mortality suggesting not to use it as monotherapy $[18,19]$. Nevertheless, any study which would evaluate the efficacy of tigecycline in combination therapy regimens will have the same major disadvantage. The facts that most of the cases were from Turkey and there were mortality, relapse and reinfection after the end of successful CRAB meningitis therapy, suggest problems in infection control. Despite the above-mentioned limitations, to our knowledge, this is the largest series and dataset evaluating the microbiological and clinical efficacy of tigecycline in CRAB meningitis and comparing tigecycline monotherapy with combination therapy.

\section{Conclusion}

Our experience with tigecycline including therapy modalities resulted in an EOT success of $70 \%$ but since further $27 \%$ died due to other nosocomial infections, overall clinical success (relieved symptoms at the end of treatment and one-month post-therapy survival without any relapse or reinfection) decreased to $43 \%$. These data suggest that similar to colistin [34], tigecycline can be an alternative in the salvage therapy of nosocomial CRAB meningitis. The medical community should seek easily implementable-very fastly resulting synergy testing methods in the contemporary age of antibiotic therapy, which includes only a few alternatives for CRAB. In addition, the Turkish medical community should seek effective infection control measures regarding CRAB meningitis and other nosocomial infections. We recommend physicians treating any patient with tigecycline to determine actual CSF levels of the drug (whereever the measurement of tigecycline is abailable), along with CSF data which could allow them to correlate CSF levels with penetration across an inflamed blood-brain barrier and maintenance of levels as therapy progresses.

Acknowledgments: Authors thank European Study Group for Infections of Brain (Esgib). This research did not receive any specific grant from any party.

Author contributions statement: Concept/design: ORS, Data analysis/interpretation: ORS, SM, HS, Drafting article: ORS, SM, Critical revision of article: ORS, TY, HS, SU, TD, YC, ACU Approval of article: All authors, Statistics: HS, Data collection: All authors

Competing Financial Interests Statement: SU, BA, MT, HP and TD received speaker's honorarium from Pfizer. Others have no conflict of interest to declare. 


\section{References}

[1] S. Bardak-Ozcem, O.R. Sipahi, An updated approach to healthcare-associated meningitis, Expert. Rev. Anti. Infect. Ther. 12 (2014) 333-42.

[2] D. van de Beek, J.M. Drake, A.R.Tunkel, Nosocomial bacterial meningitis. N. Engl. J. Med. 362 (2010) 14654.

[3] O.R. Sipahi, A. Nazli Zeka, M. Taşbakan, H. Pullukçu, B. Arda, T. Yamazhan, H. Sipahi, S. Ulusoy, Pooled analysis of 899 nosocomial meningitis episodes from Turkey, Turk. J. Med. Sci. 47 (2017) 29-33.

[4] O.R. Sipahi, Economics of antibiotic resistance, Expert Rev. Anti. Infect. Ther. 6 (2008) 523-39.

[5] M.S. Tasbakan, H. Pullukcu, O.R. Sipahi, M.I. Tasbakan, S. Aydemir, F. Bacakoglu, Is tigecycline a good choice in the treatment of multidrug-resistant Acinetobacter baumannii pneumonia? J. Chemother. 23 (2011) $345-9$.

[6] J.A. Wadi, J.A., M.A. Al Rub, Multidrug resistant Acinetobacter nosocomial meningitis treated successfully with parenteral tigecycline. Ann. Saudi. Med. 27 (2007) 456-8.

[7] E.E. Tutuncu, F. Kuscu, Y. Gurbuz, B. Ozturk, A. Haykir, I. Sencan, Tigecycline use in two cases with multidrug-resistant Acinetobacter baumannii meningitis. Int J Infect. Dis. 14 Suppl 3 (2010) e224-6.

[8] W.Y. Kim, J.Y. Moon,J.W. Huh, S.H. Choi, C.M. Lim, Y. Koh, Y.P. Chong, S.B. Hong, Comparable Efficacy of Tigecycline versus Colistin Therapy for Multidrug-Resistant and Extensively Drug-Resistant Acinetobacter baumannii Pneumonia in Critically Ill Patients. PLoS One 11 (2016) e0150642.

[9] Y.C. Chuang, Y.C. Cheng, W.H. Sheng, H.Y. Sun, J.T.Wang, Y.C. Chen, S.C. Chang, Effectiveness of tigecycline-based versus colistin- based therapy for treatment of pneumonia caused by multidrug-resistant Acinetobacter baumannii in a critical setting: a matched cohort analysis. BMC Infect. Dis. 14 (2014) 102. [10] O.R.Sipahi, H. Kahraman, S. Mermer, H. Pullukcu, M. Tasbakan, B. Arda, T. Yamazhan, T. Yurtseven, S. Aydemir, S. Ulusoy, Tigecycline in the management of post-neurosurgical spondylodiscitis: a review of eight cases. Int. J. Infect. Dis. 23 (2014) 16-9.

[11] O.R. Sipahi, S. Bardak, T. Turhan, B. Arda, H. Pullukcu, M. Ruksen, S. Aydemir, T. Dalbasti, T. Yurtseven, M. Zileli, S. Ulusoy, Linezolid in the treatment of methicillin-resistant staphylococcal postneurosurgical meningitis: a series of 17 cases. Scand. J. Infect. Dis. 43 (2011) 757-64. 
[12] http://www.saglik.gov.tr/TR/dosya/1-97084/h/2014-ulusal-ozet-rapor-1.pdf (Last accessed September, 11, 2016)

[13] U.J. Kim, H.K. Kim, J.H. An, S.K. Cho, K.H. Park, H.C. Jang, Update on the Epidemiology, Treatment, and Outcomes of Carbapenem-resistant Acinetobacter infections, Chonnam. Med. J. 50 (2014) 37-44.

[14] C. Buke, O.R.Sipahi, T. Yurtseven, M. Zileli, High dose of intrathecal netilmicin in the treatment of nosocomial Acinetobacter baumannii meningitis., J Infect 51 (2005) 420-2.

[15] B.N. Kim, A.Y. Peleg, T.P. Lodise, J. Lipman, Li, R. Nation, D.L. Paterson. Management of meningitis due to antibiotic-resistant Acinetobacter species. Lancet Infect .Dis. 9 (2009) 245-55.

[16] I Kooli, H.B. Brahim, M. Kilani, C. Gannouni, A. Aouam, A. Toumi, C. Loussaief, M.N. Hattab, M. Chakroun, Successful treatment of postoperative multidrug-resistant Acinetobacter baumannii meningitis by tigecycline. J. Glob. Antimicrob. Resist. 5 (2016) 62-3.

[17] G.D. Fang, W.J. Weiss, W.J., W.M. Scheld, Comparative efficacy of GAR-936, a novel glycylcycline, alone and in combination with vancomycin against highly penicillin-resistant Streptococcus pneumoniae experimental meningitis in rabbits. In: Abstracts of the fortieth Interscience Conference on Antimicrobials and Chemotherapy (ICAAC); Toronto, Ontario, Canada, 2000. Abstract 868, p. 51. American Society for Microbiology, Washington, DC, USA.

[18] D. Yahav, A. Lador, M. Paul, M, L. Leibovici, Efficacy and safety of tigecycline: a systematic review and meta-analysis. J Antimicrob Chemother 66 (2011) 1963-71.

[19] P.C. McGovern, M. Wible, A. El-Tahtawy, P. Biswas, R.D. Meyer, All-cause mortality imbalance in the tigecycline phase 3 and 4 clinical trials, Int. J. Antimicrob. Agents 41 (2013) 463-7.

[20] Garner, J.S et al. CDC definitions for nosocomial infections. In: Olmsted RN, editor. APIC infection control and applied epidemiology: principles and practice. St Louis: Mosby; 1996. p. A1 -20.

[21] Clinical and Laboratory Standards Institute. Performance Standards for Antimicrobial Susceptibility Testing: Twenty-third Informational Supplement M100-S23. CLSI, Wayne, PA, USA, 2013.

[22] European Committee on Antimicrobial Susceptibility Testing Breakpoint tables for interpretation of MICs and zone diameters. Version 6.0, valid from 2016-01-01. Available from http://www.eucast.org/fileadmin/src/media/PDFs/EUCAST_files/Breakpoint_tables/v_6.0_Breakpoint_table.pdf [23] L. Ray, K. Levasseur, D.P. Nicolau, M.H. Scheetz, Cerebral spinal fluid penetration of tigecycline in a patient with Acinetobacter baumannii cerebritis. Ann Pharmacother. 44 (2010) 582-6. 
[24] C. Pallotto, M. Fiorio, A. D'Avolio, A. Sgrelli, F. Baldelli, G. Di Perri, G.V. De Socio, Cerebrospinal fluid penetration of tigecycline. Scand. J. Infect. Dis. 46 (2014) 69-72.

[25] C. Lengerke, M. Haap, F. Mayer, L. Kanz, M. Kinzig, U. Schumacher, F. Sörgel, R. Riessen, Low tigecycline concentrations in the cerebrospinal fluid of a neutropenicpatient with inflamed meninges. Antimicrob. Agents Chemother. 55 (2011) 449-50.

[26] L. Lauretti, Q.G. D'Alessandris, M. Fantoni, T. D'Inzeo, E. Fernandez, R. Pallini, G. Scoppettuolo, First reported case of intraventricular tigecycline for meningitis from extremely drug-resistant Acinetobacter baumanni J. Neurosurg. 127 (2017)370-373.

[27] Wu Y, Chen K, Zhao J, Wang Q \& Jianxin Zhou (2017): Intraventricular administration of tigecycline for the treatment of multidrug-resistant bacterial meningitis after craniotomy: a case report, J. Chemother, 30 (2018) 49-52.

[28] Y.Q. Fang, R.C. Zhan, W. Jia, B.Q. Zhang, J.J. Wang, A case report of intraventricular tigecycline therapy for intracranial infection with extremely drug resistant Acinetobacter baumannii. Medicine (Baltimore). 96 (2017) e 7703

[29] M.E. Falagas, I.A. Bliziotis, I.A. V.H. Tam, Intraventricular or intrathecal use of polymyxins in patients with Gram-negative meningitis: a systematic review of the available evidence. Int. J. Antimicrob. Agents. 29 (2007) 9-25.

[30] G. Fotakopoulos, D. Makris, M. Chatzi, E. Tsimitrea, E. Zakynthinos, K. Fountas, Outcomes in meningitis/ventriculitis treated with intravenous or intraventricular plus intravenous colistin. Acta Neurochir. (Wien) 158 (2016) 603-10.

[31] T. Khawcharoenporn, A. Apisarnthanarak, L.M. Mundy, Intrathecal colistin for drug-resistant Acinetobacter baumannii central nervous system infection: a case series and systematic review. Clin. Microbiol. Infect. 16 (2010) 888-94.

[32] G.A. March, M.A. Bratos, A meta-analysis of in vitro antibiotic synergy against Acinetobacter baumannii. J. Microbiol. Methods. 119 (2015) 31-6.

[33] J.C. Stoltzfus, Logistic regression: a brief primer. Acad. Emerg. Med. 18 (2011) 1099-104.

[34] B. Ceylan, F. Arslan, O.R. Sipahi, M. Sunbul, B. Ormen, I.N. Hakyemez, T. Turunc, Y. Y1ld1z, H. Karsen, G. Karagoz, R. Tekin, B. Hizarci, V. Turhan, S. Senol, N. Oztoprak, M. Y1lmaz, K. Ozdemir, S. Mermer, O.F. Kokoglu, A. Mert, Variables Determining Mortality in Patients With Acinetobacter baumannii Meningitis/Ventriculitis Treated With Intrathecal Colistin. Clin. Neurol. Neurosurg. 153 (2016) 43-49. 
Figures and table 
Table 1 : Clinical and laboratory findings at the start of tigecycline including therapy.

\begin{tabular}{|c|c|c|c|c|c|c|c|}
\hline $\begin{array}{c}\text { Case } \\
\mathrm{N}\end{array}$ & Gender/Age & $\begin{array}{l}\text { Fever/Disturbences in level of } \\
\text { consciousness/convulsions }\end{array}$ & $\begin{array}{l}\text { Nausea-vomiting/ } \\
\text { neck stiffness }\end{array}$ & $\begin{array}{c}\mathrm{CSF} \\
\text { leukocyte } / \mathrm{mm}^{3}\end{array}$ & $\begin{array}{l}\text { CSF protein } \\
(\mathrm{mg} / \mathrm{dl})\end{array}$ & $\begin{array}{l}\text { CSF glucose } \\
(\mathrm{mg} / \mathrm{dl})\end{array}$ & $\begin{array}{l}\text { Blood leukocyte/mm³ } \\
\text { (Blood PNL\%) }\end{array}$ \\
\hline 2 & $\mathrm{M} / 48$ & $+/+/-$ & $+/+$ & 500 & 132 & 42 & $20700(70 \%)$ \\
\hline 4 & $F / 53$ & $-/+/-$ & $-/+$ & 280 & 148 & 51 & $10300(66 \%)$ \\
\hline 5 & $\mathrm{M} / 79$ & $+/+/+$ & $+/+$ & 460 & 123 & 54 & $14700(69 \%)$ \\
\hline 7 & $\mathrm{M} / 75$ & $+/+/+$ & $-/-$ & $>1000$ & 201 & 50 & $9140(82 \%)$ \\
\hline 8 & $M / 43$ & $+/+/-$ & $-/-$ & 3450 & 2055 & 32 & $24100(94 \%)$ \\
\hline 9 & $M / 26$ & $+/+/+$ & $+/+$ & 350 & 110 & 1 & $10600(83 \%)$ \\
\hline 10 & $\mathrm{~F} /$ & \begin{tabular}{l|l|}
$-/-/-$ \\
-1
\end{tabular} & $-/-$ & $>1000$ & 167 & 43 & $20800(85.4 \%)$ \\
\hline 14 & $F / 46$ & $-/+/-$ & $+/-$ & $>1000$ & 38 & 60 & $16250(79 \%)$ \\
\hline 15 & $\mathrm{M} / 43$ & $+/+/-$ & $-/-$ & $>1000$ & 82 & 38 & $13670(76 \%)$ \\
\hline 16 & $F / 70$ & $+/+/+$ & $+/+$ & $>1000$ & 517 & 58 & $10990(86 \%)$ \\
\hline 17 & $M / 68$ & $+/+/-$ & $+/+$ & 500 & 289 & 27 & $10800(74 \%)$ \\
\hline 18 & $\mathrm{M} / ?$ & $+/+/-$ & $-/-$ & $>1000$ & 308 & 55 & $19600(88 \%)$ \\
\hline 19 & $F / 48$ & $+/-/-$ & $+/-$ & $>1000$ & 317 & 59 & $8400(82 \%)$ \\
\hline 20 & $\mathrm{M} / 25$ & $+/+/-$ & $-/-$ & 300 & 281 & 23 & $11900(75 \%)$ \\
\hline
\end{tabular}




\begin{tabular}{|l|l|l|l|l|l|l|l|}
\hline $\mathbf{2 1}$ & $\mathrm{M} / 47$ & $+/+/-$ & $+/-$ & $>1000$ & 182 & 41 & $10300(70 \%)$ \\
\hline $\mathbf{2 2}$ & $\mathrm{M} / 59$ & $+/+/-$ & $-/-$ & $>1000$ & 411 & 26 & $7460(71 \%)$ \\
\hline $\mathbf{2 3}$ & $\mathrm{M} / 37$ & $+/+/+$ & $+/+$ & 350 & 250 & 40 & $22000(75 \%)$ \\
\hline
\end{tabular}

Table 2 Susceptibility data of infecting strains, tunderlying diseases, reatment details and outcome data of the $A$. baumannii meningitis cases 


\begin{tabular}{|c|c|c|c|c|c|c|c|c|c|}
\hline $\begin{array}{l}\text { Patie } \\
\text { nt no }\end{array}$ & Bacteria & $\begin{array}{l}\text { Antibacterial } \\
\text { sensitivity pattern } \\
\text { of the infecting } A \text {. } \\
\text { baumannii strain }\end{array}$ & $\begin{array}{l}\text { Antibiotherapy in } \\
\text { the previous } 30 \\
\text { days }\end{array}$ & Underlying condition & $\begin{array}{l}\text { Treatment } \\
\text { (IV)\&duration } \\
\text { (day) }\end{array}$ & $\begin{array}{l}\text { Day 3-5 } \\
\text { CSF } \\
\text { microbiolog } \\
\text { ic response }\end{array}$ & $\begin{array}{l}\text { End of } \\
\text { treatment CSF } \\
\text { leukocyte/Cult } \\
\text { ure result }\end{array}$ & $\begin{array}{l}\text { One month } \\
\text { follow up } \\
\text { result }\end{array}$ & $\begin{array}{l}\text { Glasgow } \\
\text { coma } \\
\text { score at } \\
\text { the start } \\
\text { and end } \\
\text { of } \\
\text { tigecycli } \\
\text { ne } \\
\text { therapy }\end{array}$ \\
\hline 1 & $\begin{array}{l}A . \\
\text { baumanni }\end{array}$ & Tigecycline, colistin & No antibiotic & $\begin{array}{l}\text { Cranial mass, lumbar } \\
\text { drainage }\end{array}$ & $\begin{array}{l}\text { Tigecycline } \\
2 \times 50 \quad \mathrm{mg} \mathrm{(16} \\
\text { days) }\end{array}$ & $\begin{array}{l}\text { Bacterial } \\
\text { eradication }\end{array}$ & $\begin{array}{l}\text { Bacterial } \\
\text { eradication }\end{array}$ & $\begin{array}{l}\text { No relapse or } \\
\text { reinfection }\end{array}$ & $7 / 14$ \\
\hline 2 & $\begin{array}{l}A . \\
\text { baumanni }\end{array}$ & Tigecycline, colistin & No antibiotic & $\begin{array}{l}\text { Intracerebral } \\
\text { hemorrhage, lumbar } \\
\text { drainage }\end{array}$ & $\begin{array}{l}\text { Tigecycline } \\
2 \times 50 \quad \mathrm{mg} \mathrm{(13} \\
\text { days) }\end{array}$ & $\begin{array}{l}\text { Bacterial } \\
\text { eradication }\end{array}$ & $\begin{array}{l}\text { Bacterial } \\
\text { eradication }\end{array}$ & $\begin{array}{l}\text { No relapse or } \\
\text { reinfection }\end{array}$ & $9 / 14$ \\
\hline 3 & $\begin{array}{l}A . \\
\text { baumanni }\end{array}$ & Tigecycline, colistin & No antibiotic & $\begin{array}{l}\text { Intracerebral } \\
\text { hemorrhage, lumbar } \\
\text { drainage }\end{array}$ & $\begin{array}{l}\text { Tigecycline } \\
2 \times 50 \quad \mathrm{mg} \quad(21 \\
\text { days })\end{array}$ & $\begin{array}{l}\text { Bacterial } \\
\text { eradication }\end{array}$ & $\begin{array}{l}\text { Bacterial } \\
\text { eradication }\end{array}$ & $\begin{array}{l}\text { Exitus during } \\
\text { follow up due } \\
\text { to nosocomial } \\
\text { pneumonia }\end{array}$ & $9 / 14$ \\
\hline 4 & $\begin{array}{l}A . \\
\text { baumanni }\end{array}$ & Tigecycline, colistin & Ceftriaxone & $\begin{array}{l}\text { Traumatic brain injury, } \\
\text { lumbar drainage }\end{array}$ & $\begin{array}{l}\text { Tigecycline } \\
2 \times 50 \quad \mathrm{mg} \quad(12\end{array}$ & $\begin{array}{l}\text { Bacterial } \\
\text { eradication }\end{array}$ & $\begin{array}{l}\text { Bacterial } \\
\text { eradication }\end{array}$ & $\begin{array}{l}\text { Exitus during } \\
\text { follow up due }\end{array}$ & $7 / 9$ \\
\hline
\end{tabular}




\begin{tabular}{|c|c|c|c|c|c|c|c|c|c|}
\hline & & & & 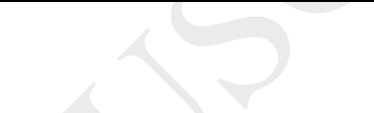 & days) & & & $\begin{array}{l}\text { to nosocomial } \\
\text { pneumonia }\end{array}$ & \\
\hline 5 & $\begin{array}{l}A . \\
\text { baumanni }\end{array}$ & Tigecycline, colistin & Ampicillin/sulbactam & $\begin{array}{l}\text { Subarachnoid bleeding, } \\
\text { shunt infection, lumbar } \\
\text { drainage, }\end{array}$ & $\begin{array}{l}\text { Tigecycline } \\
2 \times 50 \quad \mathrm{mg} \quad(5 \\
\text { days })\end{array}$ & No data & No data & $\begin{array}{l}\text { Exitus on day } \\
5 \text { of treatment } \\
\text { due to } \\
\text { meningitis/sep } \\
\text { sis. }\end{array}$ & 6/exitus \\
\hline 6 & $\begin{array}{l}A . \\
\text { baumanni }\end{array}$ & Tigecycline, colistin & No antibiotic & $\begin{array}{l}\text { Traumatic brain injury, } \\
\text { shunt infection, lumbar } \\
\text { drainage }\end{array}$ & $\begin{array}{l}\text { Tigecycline } \\
2 \times 50 \mathrm{mg} \mathrm{(11} \\
\text { days) }\end{array}$ & $\begin{array}{l}\text { Bacterial } \\
\text { eradication }\end{array}$ & $\begin{array}{l}\text { Bacterial } \\
\text { eradication }\end{array}$ & $\begin{array}{l}\text { Exitus during } \\
\text { follow up due } \\
\text { to nosocomial } \\
\text { pneumonia }\end{array}$ & $7 / 8$ \\
\hline 7 & $\begin{array}{l}A . \\
\text { baumanni }\end{array}$ & $\begin{array}{l}\text { Tigecycline, colistin, } \\
\text { tetracycline, } \\
\text { doxycycline }\end{array}$ & $\begin{array}{l}\text { Piperacillin/tazobact } \\
\text { am }\end{array}$ & Subdural hematoma & $\begin{array}{l}\text { Tigecycline } \\
2 \times 50 \mathrm{mg} \mathrm{(54} \\
\text { days)+colistin } \\
3 \times 150 \mathrm{mg} \mathrm{(13} \\
\text { days) }\end{array}$ & No data & No data & $\begin{array}{l}\text { No relapse or } \\
\text { reinfection }\end{array}$ & $9 / 14$ \\
\hline 8 & $\begin{array}{l}A . \\
\text { baumanni }\end{array}$ & Tigecycline & $\begin{array}{l}\text { Ceftriaxone, } \\
\text { metronidazole, } \\
\text { chloramphenicole }\end{array}$ & $\begin{array}{l}\text { Subacute hematoma, } \\
\text { lumbar drainage }\end{array}$ & $\begin{array}{l}\text { Tigecycline } \\
2 \times 50 \mathrm{mg} \mathrm{(23} \\
\text { days)+colistin } \\
2 \times 150 \mathrm{mg} \mathrm{(23} \\
\text { days) }\end{array}$ & $\begin{array}{l}2800 \\
\text { leukocytes/ } \\
\mathrm{mm}^{3} / \\
\text { A. } \\
\text { baumannii }\end{array}$ & $\begin{array}{l}2800 \\
\text { leukocytes/mm } \\
3 / \\
\text { A. baumannii }\end{array}$ & $\begin{array}{l}\text { Exitus on day } \\
23 \\
\text { treatment due } \\
\text { to meningitis } \\
\text { and possible }\end{array}$ & 4/exitus \\
\hline
\end{tabular}




\begin{tabular}{|c|c|c|c|c|c|c|c|c|c|}
\hline & & & & & & & & $\begin{array}{l}\text { catheter } \\
\text { infection }\end{array}$ & \\
\hline 9 & $\begin{array}{l}A . \\
\text { baumanni }\end{array}$ & Tigecycline, colistin & No antibiotic & $\begin{array}{l}\text { V-P shunt revision, shunt } \\
\text { infection, }\end{array}$ & 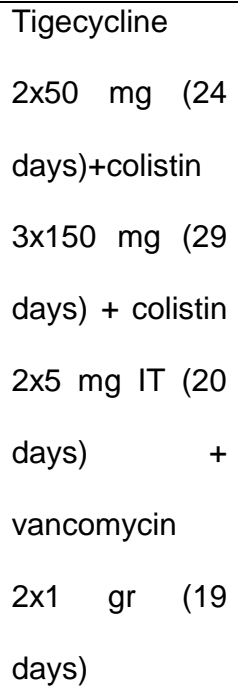 & $\begin{array}{l}80 \\
\text { leukocytes/ } \\
\mathrm{mm}^{3} \\
\text { Bacterial } \\
\text { eradication }\end{array}$ & $\begin{array}{l}\text { No leukocyte } \\
/ \mathrm{mm}^{3} \\
\text { Bacterial } \\
\text { eradication }\end{array}$ & $\begin{array}{l}\text { Exitus at the } \\
\text { end } \\
\text { treatment }\end{array}$ & 7/exitus \\
\hline 10 & $\begin{array}{l}A . \\
\text { baumanni }\end{array}$ & $\begin{array}{l}\text { Tigecycline, } \\
\text { amikacin, colistin }\end{array}$ & $\begin{array}{l}\text { Cefazolin, } \\
\text { meropenem, } \\
\text { linezolid }\end{array}$ & $\begin{array}{l}\text { Nasal encephalocele, } \\
\text { lumbar drainage }\end{array}$ & $\begin{array}{l}\text { Tigecycline } \\
2 \times 50 \mathrm{mg} \mathrm{(26} \\
\text { days)+colistin } \\
2 \times 150 \mathrm{mg} \mathrm{(26} \\
\text { days) }\end{array}$ & $\begin{array}{l}10 \\
\text { leukocytes/ } \\
\mathrm{mm}^{3} \\
\text { Bacterial } \\
\text { eradication }\end{array}$ & $\begin{array}{l}\text { Bacterial } \\
\text { eradication }\end{array}$ & $\begin{array}{l}\text { No relapse or } \\
\text { reinfection }\end{array}$ & $15 / 15$ \\
\hline 11 & $\begin{array}{l}A . \\
\text { baumanni }\end{array}$ & $\begin{array}{l}\text { Tigecycline, colistin, } \\
\text { ciprofloxacin, } \\
\text { netilmicin, } \\
\text { tetracycline, }\end{array}$ & $\begin{array}{l}\text { Piperacillin/tazobact } \\
\text { am, colistin } \\
\text { (nephrotoxicity) }\end{array}$ & $\begin{array}{l}\text { Gun shot injury, } \\
\text { extraventricular drainage }\end{array}$ & \begin{tabular}{l}
\multicolumn{3}{l}{ Tigecycline } \\
$2 \times 50 \quad \mathrm{mg} \quad(7$ \\
days), colistin \\
$2 \times 150 \quad \mathrm{mg}$
\end{tabular} & No data & No data & $\begin{array}{l}\text { Exitus during } \\
\text { treatment } \\
\text { possibly due } \\
\text { to meningitis. }\end{array}$ & 6/exitus \\
\hline
\end{tabular}




\begin{tabular}{|c|c|c|c|c|c|c|c|c|c|}
\hline & & $\begin{array}{l}\text { levofloxacin; } \\
\text { amikacin } \\
\text { imipenem } \\
\text { meropenem (I), }\end{array}$ & & 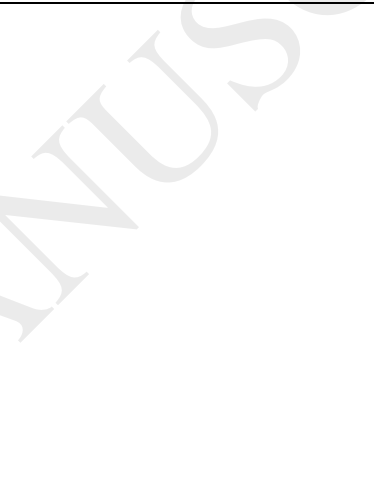 & $\begin{array}{l}\text { followed by } \\
\text { meropenem } \\
3 \times 2 \text { gr (12 } \\
\text { days),, } \\
\text { vancomycin } \\
2 \times 1 \quad \text { gr } \quad(3 \\
\text { days), }\end{array}$ & & & & \\
\hline 12 & $\begin{array}{l}\text { A.bauma } \\
\text { nni } E . \\
\text { faecium }\end{array}$ & $\begin{array}{l}\text { Tigecycline, colistin, } \\
\text { amikacin, netilmicin, } \\
\text { levofloxacin (I) }\end{array}$ & $\begin{array}{l}\text { Cefazolin, } \\
\text { ceftriaxone, } \\
\text { metronidazole }\end{array}$ & $\begin{array}{l}\text { Epidural and subdural } \\
\text { hematoma }\end{array}$ & $\begin{array}{l}\text { Tigecycline } \\
2 \times 50 \mathrm{mg} \mathrm{(16} \\
\text { days)+merope } \\
\text { nem 3x2 gr (14 } \\
\text { days) } \\
\text { vancomycin } \\
2 \times 1 \quad \text { gr (18 } \\
\text { days), colistin } \\
2 \times 150 \mathrm{mg} \text { (24 } \\
\text { days) }\end{array}$ & $\begin{array}{l}50 \\
\text { leukocytes/ } \\
\mathrm{mm}^{3} \\
\text { Bacterial } \\
\text { eradication }\end{array}$ & No data & $\begin{array}{l}\text { No relapse or } \\
\text { reinfection }\end{array}$ & $10 / 11$ \\
\hline 13 & $\begin{array}{l}A . \\
\text { baumanni }\end{array}$ & $\begin{array}{l}\text { Tigecycline } \\
\text { (MIC:0.5 } \mathrm{mg} / \mathrm{L} \text { ), } \\
\text { gentamicin, } \\
\text { tobramicin, }\end{array}$ & $\begin{array}{l}\text { Ceftriaxone, } \\
\text { vancomycin }\end{array}$ & $\begin{array}{l}\text { Aneurysm; } \\
\text { subarachnoid bleeding, } \\
\text { extraventricular drainage }\end{array}$ & $\begin{array}{l}\text { Tigecycline } \\
2 \times 50 \mathrm{mg} \mathrm{(67} \\
\text { days) + colistin } \\
2 \times 150 \mathrm{mg} \quad(63\end{array}$ & $\begin{array}{l}800 \\
\text { leukocytes/ } \\
\mathrm{mm}^{3} / A . \\
\text { baumannii }\end{array}$ & $\begin{array}{l}\text { No leukocyte / } \\
\text { Bacterial } \\
\text { eradication }\end{array}$ & $\begin{array}{l}\text { No relapse or } \\
\text { reinfection, } \\
\text { reshunting }\end{array}$ & $13 / 13$ \\
\hline
\end{tabular}




\begin{tabular}{|c|c|c|c|c|c|c|c|c|c|}
\hline & & $\begin{array}{l}\text { netilmicin,; } \\
\text { cotrimoxasole (I) }\end{array}$ & & & $\begin{array}{l}\text { days) }+ \text { colistin } \\
2 \times 5 \quad \mathrm{mg} \\
\text { intrathecal (19 } \\
\text { days) }\end{array}$ & & & & \\
\hline 14 & $\begin{array}{l}A . \\
\text { baumanni }\end{array}$ & $\begin{array}{l}\text { Tigecycline } \\
\text { (MIC:0.5 } \mathrm{mg} / \mathrm{L} \text { ), } \\
\text { colistin gentamicin, } \\
\text { netilmicin, amikacin } \\
\text { (I) }\end{array}$ & $\begin{array}{l}\text { Cefazolin, } \\
\text { meropenem, } \\
\text { vancomycin, } \\
\text { cefepime, linezolid }\end{array}$ & $\begin{array}{l}\text { Aneurysm; } \\
\text { subarachnoid bleeding, } \\
\text { extraventricular drainage }\end{array}$ & $\begin{array}{l}\text { Tigecycline } \\
2 \times 50 \mathrm{mg} \mathrm{(68} \\
\text { days) + colistin } \\
2 \times 150 \mathrm{mg} \mathrm{(14} \\
\text { days) } \\
\text { rifampin } 1 \times 600 \\
\text { mg (54 days) }\end{array}$ & $\begin{array}{l}00 \\
\text { leukocytes/ } \\
\mathrm{mm}^{3} \\
\text { Bacterial } \\
\text { eradication }\end{array}$ & $\begin{array}{l}\text { No leukocyte / } \\
\text { Bacterial } \\
\text { eradication }\end{array}$ & $\begin{array}{l}\text { No relapse or } \\
\text { reinfection }\end{array}$ & $12 / 11$ \\
\hline 15 & b. & $\begin{array}{l}\text { Tigecycline, colistin, } \\
\text { gentamicin, } \\
\text { netilmicin } \\
\text { doxycycline } \\
\text { amikacin } \\
\text { levofloxacin (I) }\end{array}$ & $\begin{array}{l}\text { Meropenem, } \\
\text { vancomycin }\end{array}$ & $\begin{array}{l}\text { Subdural hemorrhage, } \\
\text { shunt infection }\end{array}$ & $\begin{array}{l}\text { Tigecycline } \\
2 \times 50 \mathrm{mg} \text { (24 } \\
\text { days) + colistin } \\
2 \times 150 \mathrm{mg} \text { (24 } \\
\text { days) + colistin } \\
2 \times 5 \quad \mathrm{mg} \\
\text { intrathecal (22 } \\
\text { days) }\end{array}$ & $\begin{array}{l}120 \\
\text { leukocytes/ } \\
\mathrm{mm}^{3} / A . \\
\text { baumannii }\end{array}$ & $\begin{array}{l}\text { No leukocyte / } \\
\text { Bacterial } \\
\text { eradication }\end{array}$ & $\begin{array}{l}\text { Relapse } A . \\
\text { baumannii } \\
\text { meningitis on } \\
\text { day } 22\end{array}$ & $10 / 10$ \\
\hline 16 & $\begin{array}{l}A . \\
\text { baumanni }\end{array}$ & $\begin{array}{l}\text { Tigecycline, } \\
\text { cotrimoxasole, }\end{array}$ & $\begin{array}{l}\text { Ceftazidime, } \\
\text { vancomycin }\end{array}$ & Lumbar spinal stenosis & $\begin{array}{l}\text { Tigecycline } \\
2 \times 50 \quad \mathrm{mg} \quad(18\end{array}$ & $\begin{array}{l}>1000 \\
\text { leukocytes/ }\end{array}$ & $\begin{array}{l}\text { No leukocyte / } \\
\text { Bacterial }\end{array}$ & $\begin{array}{l}\text { Exitus on day } \\
18 \quad \text { of }\end{array}$ & 9/Exitus \\
\hline
\end{tabular}




\begin{tabular}{|c|c|c|c|c|c|c|c|c|c|}
\hline & & $\begin{array}{l}\text { netilmicin, } \\
\text { doxycycline (I) }\end{array}$ & & & $\begin{array}{l}\text { days) } \\
\text { netilmicin } \\
1 \times 150 \mathrm{mg} \text { it ( } 3 \\
\text { days) followed } \\
\text { by } 1 \times 400 \mathrm{mg} \\
\text { IV (6 days) } \\
\text { followed by } \\
\text { colistin } 2 \times 150 \\
\text { mg (9 days) }\end{array}$ & $\begin{array}{l}\mathrm{mm}^{3} / A . \\
\text { baumannii }\end{array}$ & eradication & $\begin{array}{l}\text { treatment } \\
\text { possibly due } \\
\text { to } P \text {. stuartii } \\
\text { sepsis. }\end{array}$ & \\
\hline 17 & $\begin{array}{l}\text { A. } \\
\text { baumanni }\end{array}$ & $\begin{array}{l}\text { Tigecycline, } \\
\text { ceftazidime, } \\
\text { doxycycline, } \\
\text { netilmicin, } \\
\text { cefoperazone/sulba } \\
\text { ctam (I), amikacin } \\
\text { (I) }\end{array}$ & $\begin{array}{l}\text { Meropenem, } \\
\text { vancomycin }\end{array}$ & $\begin{array}{l}\text { Subarachnoid bleeding, } \\
\text { hydrocephalus, } \\
\text { extraventricular drainage }\end{array}$ & 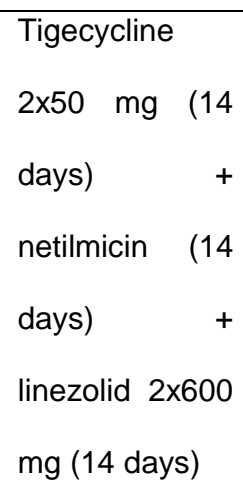 & $\begin{array}{l}\text { No leukocyte } \\
\text { Bacterial } \\
\text { eradication }\end{array}$ & No data & $\begin{array}{l}\text { Exitus on day } \\
14 \\
\text { treatment } \\
\text { possibly due } \\
\text { to meningitis. }\end{array}$ & 13/Exitus \\
\hline 18 & $\begin{array}{l}A . \\
\text { baumanni }\end{array}$ & Tigecycline & $\begin{array}{l}\text { Cefazolin, } \\
\text { cefoperazone/sulba } \\
\text { ctam, meropenem }\end{array}$ & $\begin{array}{l}\text { Intracerebral } \\
\text { hemorrhage, lumbar } \\
\text { drainage }\end{array}$ & $\begin{array}{l}\text { Tigecycline } \\
2 \times 50 \mathrm{mg}, \quad(18 \\
\text { days) } \\
\text { netilmicin } \\
1 \times 400 \mathrm{mg} \quad(18\end{array}$ & $\begin{array}{l}240 \\
\text { leukocytes/ } \\
\mathrm{mm}^{3} \\
\text { Bacterial } \\
\text { eradication }\end{array}$ & $\begin{array}{l}\text { No leukocyte / } \\
\text { Bacterial } \\
\text { eradication }\end{array}$ & $\begin{array}{l}\text { Reinfection } \\
(M R S A)\end{array}$ & $6 / 7$ \\
\hline
\end{tabular}




\begin{tabular}{|c|c|c|c|c|c|c|c|c|c|}
\hline & & & & & days) & & & & \\
\hline 19 & $\begin{array}{l}A . \\
\text { baumanni }\end{array}$ & $\begin{array}{l}\text { Colistin, tigecycline, } \\
\text { netilmicin }\end{array}$ & $\begin{array}{l}\text { Cefazolin, } \\
\text { meropenem, } \\
\text { vancomycin }\end{array}$ & $\begin{array}{l}\text { Pituitary gland adenoma } \\
\text { adenoma, rhinorrhea }\end{array}$ & 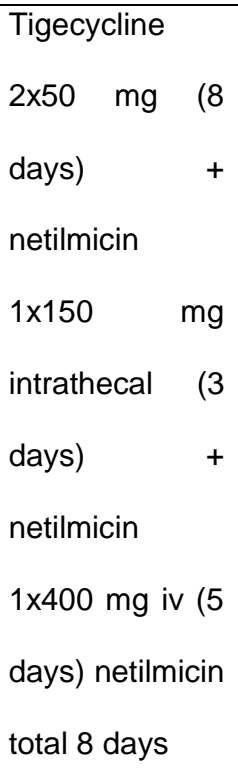 & No data & No data & $\begin{array}{l}\text { No relapse or } \\
\text { reinfection }\end{array}$ & $15 / 15$ \\
\hline 20 & $\begin{array}{l}A . \\
\text { baumanni }\end{array}$ & $\begin{array}{l}\text { Tigecycline, } \\
\text { amikacin, } \\
\text { doxycycline }\end{array}$ & Vancomycin & $\begin{array}{l}\text { Hydrocephalus }+\mathrm{VP} \\
\text { shunt dysfunction, } \\
\text { extraventricular drainage }\end{array}$ & $\begin{array}{l}\text { Tigecycline } \\
2 \times 50 \quad \mathrm{mg} \quad(25 \\
\text { days }) \\
\text { amikacin } \\
2 \times 500 \mathrm{mg} \quad(25 \\
\text { days })\end{array}$ & $\begin{array}{l}80 \\
\text { leukocytes/ } \\
\mathrm{mm}^{3} \\
\text { A.baumannii }\end{array}$ & $\begin{array}{l}\text { No leukocyte / } \\
\text { Bacterial } \\
\text { eradication }\end{array}$ & $\begin{array}{l}\text { No relapse or } \\
\text { reinfection }\end{array}$ & $10 / 9$ \\
\hline 21 & $\begin{array}{l}A . \\
\text { baumanni }\end{array}$ & $\begin{array}{l}\text { Tigecycline, } \\
\text { netilmicin, }\end{array}$ & $\begin{array}{l}\text { Piperacillin/tazobact } \\
\text { am, ciprofloxacin, }\end{array}$ & $\begin{array}{l}\text { Intracerebral } \\
\text { hemorrhage, }\end{array}$ & $\begin{array}{l}\text { Tigecycline } \\
2 \times 50 \quad \mathrm{mg} \quad(14\end{array}$ & No data & $\begin{array}{l}>1000 \\
\text { leukocytes } / \mathrm{mm}\end{array}$ & $\begin{array}{l}\text { Reinfection } \\
\text { (P. aeruginosa }\end{array}$ & $5 / 5$ \\
\hline
\end{tabular}




\begin{tabular}{|c|c|c|c|c|c|c|c|c|c|}
\hline & & $\begin{array}{l}\text { cefoperazone/sulba } \\
\text { ctam }\end{array}$ & linezolid, teicoplanin & $\begin{array}{l}\text { hydrocephalus, } \\
\text { shunt infection }\end{array}$ & $\begin{array}{l}\text { days) } \\
\text { amikacin } \\
2 \times 500 \mathrm{mg}(14 \\
\text { days) } \\
\text { rifampin 2x300 } \\
\text { mg (14 days) }\end{array}$ & & $\begin{array}{l} \\
\text { P.aeruginosa }\end{array}$ & meningitis) & \\
\hline 22 & $\begin{array}{l}A . \\
\text { baumanni }\end{array}$ & $\begin{array}{l}\text { Tigecycline, colistin, } \\
\text { amikacin } \\
\text { imipenem (I), } \\
\text { meropenem (I) }\end{array}$ & $\begin{array}{l}\text { Ceftazidime, } \\
\text { vancomycin, } \\
\text { meropenem, } \\
\text { liinezolid }\end{array}$ & $\begin{array}{l}\text { Cerebral abscess, } \\
\text { extraventricular drainage }\end{array}$ & $\begin{array}{l}\text { Tigecycline } \\
(26 \\
\text { days)+merope } \\
\text { nem (33 days) } \\
+ \text { amikacin (23 } \\
\text { days, IT) }\end{array}$ & $\begin{array}{l}>1000 \\
\text { leukocytes/ } \\
\mathrm{mm}^{3} \\
\text { Bacterial } \\
\text { eradication }\end{array}$ & $\begin{array}{l}300 \\
\text { leukocytes } / \mathrm{mm} \\
3 / \text { Bacterial } \\
\text { eradication }\end{array}$ & $\begin{array}{l}\text { Exitus on day } \\
26 \\
\text { treatment }\end{array}$ & 7/Exitus \\
\hline 23 & $\begin{array}{l}A . \\
\text { baumanni }\end{array}$ & Tigecycline, colistin & Ciprofloxacin & $\begin{array}{l}\text { Subdural hematoma, } \\
\text { cervical } 3-4 \text { fracture, } \\
\text { hydrocephalus, extraventr } \\
\text { icular drainage }\end{array}$ & $\begin{array}{l}\text { Tigecycline } \\
2 \times 50 \mathrm{mg} \mathrm{(21} \\
\text { days)+ } \\
\text { meropenem } \\
3 \times 2 \mathrm{gr} \quad(21 \\
\text { days) }\end{array}$ & $\begin{array}{l}80 \\
\text { leukocytes/ } \\
\mathrm{mm}^{3} \\
\text { Bacterial } \\
\text { eradication }\end{array}$ & $\begin{array}{l}10 \\
\text { leukocytes } / \mathrm{mm} \\
3 / \text { Bacterial } \\
\text { eradication }\end{array}$ & $\begin{array}{l}\text { No relapse or } \\
\text { reinfection }\end{array}$ & $8 / 12$ \\
\hline
\end{tabular}

Table 3: Summary of microbiological rsponse as well as clinical response at the end of therapy and one month follow up data. 


\begin{tabular}{|c|c|c|c|c|c|}
\hline & $\begin{array}{c}\text { Tigecycline } \\
\text { monotherapy } \\
\text { (n:6) }\end{array}$ & $\begin{array}{c}\text { Colistin including } \\
\text { therapy } \\
(n: 10)\end{array}$ & $\begin{array}{c}\text { Netilmicin including } \\
\text { therapy }(n: 4)\end{array}$ & $\begin{array}{c}\text { Amikacin including } \\
\text { therapy }(\mathrm{n}: 3)\end{array}$ & $\begin{array}{c}\text { Meropenem } \\
\text { including therapy } \\
(\mathrm{n}: 4)\end{array}$ \\
\hline $\begin{array}{l}\text { Day 3-5 bacteriological } \\
\text { response }\end{array}$ & $5 / 5$ & $4 / 8$ & $2 / 3$ & $1 / 2$ & $3 / 3$ \\
\hline $\begin{array}{l}\text { End of treatment clinical } \\
\text { success }\end{array}$ & $5 / 6$ & $6 / 10$ & $2 / 4$ & $2 / 3$ & $2 / 4$ \\
\hline $\begin{array}{l}\text { Post treatment one } \\
\text { month survival without } \\
\text { relapse or reinfection }\end{array}$ & $2 / 6$ & $5 / 10$ & $1 / 4$ & $1 / 3$ & $2 / 4$ \\
\hline
\end{tabular}

